\title{
Effect of Storage on the Quality of Value Added Snacks Developed Using Partially Defatted Peanut Cake Flour and Fenugreek Leaves Powder
}

\author{
T. Bindhya Dhanesh ${ }^{1 *}$, Anita Kochhar ${ }^{1}$ and M. Javed ${ }^{2}$ \\ ${ }^{1}$ Department of Food and Nutrition, College of Home Science, Punjab Agricultural \\ University, Ludhiana, Punjab, India \\ ${ }^{2}$ Department of Stat, Math and Physics, College of Basic Sciences, Punjab Agricultural \\ University, Ludhiana, Punjab, India \\ *Corresponding author
}

\begin{abstract}
A B S T R A C T
\section{Keywords}

Partially defatted peanut cake flour, Nutritional parameters, Microbial quality, Aflatoxin, Total plate count, Fungal count

Article Info

Accepted:

10 January 2018

Available Online:

10 February 2018

Traditional Indian snacks namely Matthi and Seviya using partially defatted peanut cake flour at 10 per cent level and powdered fenugreek leaves powder at 1 per cent level were developed with an aim to eradicate malnutrition. The freshly prepared products were analysed for their nutritional parameters. The products were stored in three different packaging materials like glass jars, aluminium zip pouch + glass jar and plastic zip pouch + glass jar for a period of 90 days at ambient temperature. They were analysed for their nutritional parameters after 90 days of storage and microbial quality every fortnightly. Shelf life studies revealed that the although the proximate and mineral composition of all the products reduced in all three packaging materials, the composition was better retained in glass jars, aluminium zip pouch + glass jar when compared to the products stored in plastic zip lock pouch + glass jar. Aflatoxin was also not detected in any of the products. The microbial quality of the products reduced after 60 days of storage. Total plate count and fungal counts were higher for products stored in plastic zip lock pouch + glass jar. However, pathogenic micro-organisms like E. coli and Staphylococcus spp. were not detected.
\end{abstract}

\section{Introduction}

Partially defatted peanut cake flour is an underutilized by products obtained after the extraction of oil. It has rich nutritional profile with 45-60 per cent protein, 22-30 per cent carbohydrate, 3.8-7.5 per cent fiber and 4-6 per cent minerals (Desai et al., 1999). This nutritious by products is indigenously used as cattle feed and manure in most parts of the world. It is gluten-free and can be substituted in various products as a beneficial ingredient. Although it has been used as a food ingredient, many are not aware of its nutritional potentials. India is one among those countries were partially defatted peanut cake flour is still used a cattle feed or manure. India is also a country with a high prevalence rate of undernourished children. Utilization of partially defatted peanut cake flour in various traditional recipes and bakery products can enhance the protein content of the products 
and serve as an excellent vehicle for enhancing the utilization of groundnut protein in the diets of malnourished people in most of the developing countries. Other than its nutritional potentials, it is low in fat and thus can be used in weight watch diets. Utilization of defatted groundnut meal with mild processing treatment is becoming increasingly popular in other countries. However, in India because of the unhygienic processing conditions that prevail in many small-scale oilseeds processing factories/units the residual cake/meal is generally not fit for human consumption, but is only suitable for animal feed or as an ingredient of nitrogenous fertilizer (Ali, 1995).

Food packaging is one of the most important aspects while storing partially defatted peanut cake flour or products prepared from the same as some amount of oil remains in the cake after the oil extraction. Appropriate food packaging materials should be used as it can retard product deterioration, retain the beneficial effects of processing, extend shelflife, and maintain or increase the quality and safety of food (Kenneth and Betty, 2007). Food packages provide protection from 3 major classes of external influences: chemical, biological, and physical (Hotchkins, 1997). Chemical protection minimizes compositional changes triggered by environmental influences such as exposure to gases (typically oxygen), moisture (gain or loss), or light (visible, infrared, or ultraviolet). Glass and metals are ones among that provide chemical and physical barriers. Closure devices may contain materials that allow minimal levels of permeability. For example, plastic caps have some permeability to gases and vapors, as do the gasket materials used in caps to facilitate closure and in metal can lids to allow sealing after filling (APC, 2004). Plastic packaging offers a large range of barrier properties but is generally more permeable than glass or metal. Biological protection prevents the entry of pathogenic and spoilage microorganisms, insects, rodents, and other animals, thereby preventing disease and spoilage.

Thus, Package design and construction play a significant role in determining the shelf life of a food product. The selection of appropriate packaging materials and technologies for food maintains product quality and freshness during distribution and storage. Materials that have traditionally been used in food packaging include glass, metals (aluminum, foils and laminates, tinplate, and tin-free steel), paper and paperboards, and plastics (Kenneth and Betty, 2007). In the recent years, food packaging involves combining several materials to effectively utilise each material's functional or aesthetic properties. Hence, the purpose of this study was to compare the shelf life on the nutritional and microbial quality of value added products prepared using partially defatted peanut cake flour in three different packages and to select which ever be appropriate.

\section{Materials and Methods}

\section{Procurement and processing of raw materials}

Ingredients required for the development of value added products like Wheat flour, Chick pea flour, Raw peanuts, fenugreek leaves as well as other ingredients like oil, ghee, salt, carom seeds etc. were procured from the local market of Ludhiana in a single lot.

Peanuts were purchased and checked for any infestation or damage. They were then roasted, de-skinned. Oil was extracted by using oil extraction machine. The residual cake was collected and dried in the oven at $65{ }^{\circ} \mathrm{C}$ for half an hour. Dried cake was ground to fine powder. Green leafy vegetable like spinach and fenugreek leaves were procured dried in a tray drier at $60^{\circ} \mathrm{C}$ for 5-6 hours (constant 
weight was achieved in this time). The dried spinach and fenugreek leaves were ground to fine powder stored in separate airtight containers.

Formulation and development of the products

Two traditional Indian namkeens namely Matthi and Seviyan were developed keeping the basic ingredient used for all the products as cereal-pulse mix flour. Pulse flour was taken in one-third amount of cereal flour.

This mix was replaced for the main ingredient listed in the standard procedure. Wheat flour was used as a cereal source and chickpea flour was used as a pulse source. The standard procedures used for product development were as follows:

\section{Matthi}

\section{Ingredients}

Wheat flour- $66.5 \mathrm{~g}$

Chick pea flour $-22.5 \mathrm{~g}$

Dalda $-7 \mathrm{~g}$

Fenugreek leaves powder- $1 \mathrm{~g}$

Carom seeds and salt as required

\section{Procedure}

Wheat flour, chick pea flour, fenugreek leaves powder, carom seeds and salt (1/2 tsp) is mixed with $7 \mathrm{~g}$ of dalda thoroughly. Stiff dough is prepared using water. Small balls are rolled out from the dough and flattened. They are then pricked with fork and deep fried in oil

\section{Seviyan}

\section{Ingredients}

Chick pea flour- $66.5 \mathrm{~g}$

Wheat flour $-22.5 \mathrm{~g}$
Fenugreek leaves powder- $1 \mathrm{~g}$

Oil $-5 \mathrm{ml}$

Salt for taste

\section{Procedure}

Chick pea flour, wheat flour and fenugreek leaves powder is mixed with salt and soft dough is prepared using water and $5 \mathrm{ml}$ of oil. It is then filled into a Seviyan machine. The dough is then extruded out into hot oil and deep fried.

\section{Storage of the products}

The developed value added products were then storage separately in three packaging materials namely glass jars, aluminium zip lock pouch + glass jar and plastic zip lock pouch + glass jar to compare the shelf life quality of the products at $\left(30 \pm 2^{0} \mathrm{C}\right)$ for a periods of 90 days.

\section{Nutritional analysis of the value added products}

The developed value added products were then subjected to nutritional analysis for proximate and mineral using standard procedures. Invitro protein digestibility was also analysed. The analysis was conducted before and after storage of the products in different packaging materials

\section{Proximate composition}

Proximate composites like Moisture, Crude Protein, Crude Fat, Crude Fiber, Crude Ash, Carbohydrates and Energy were analysed using standard procedures suggested by AOAC (2000).

\section{Minerals}

Elements namely iron and calcium were estimated using atomic absorption 
spectrophotometer (AAS, Varian model) after wet digestion (Piper, 1950).

\section{In vitro protein digestibility}

It was carried out by the by macro kjeldahl method (Akeson and Stachman, 1964).

\section{Aflatoxins}

The samples were extracted by using the method of Barabalok et al., (1974) and further detected using the Pressure Mini Column methods (PCM) Sashidhar et al., (1989).

Microbial estimation of the value added products

The products from different packaging materials were estimated for their microbial quality every fortnightly using standard procedures (David and Frankhausar 2010). The parameters analysed and respective media used are as follows:

\section{Statistical Analysis}

The nutritional attributes were analysed using paired t-test for fresh and stored samples. While to compare the quality of the products between the packaging materials, one-way anova was applied. The values are expressed as Mean \pm SE (Standard error)

\section{Results and Discussion}

The effect of storage on the value added products developed incorporating partially defatted peanut cake flour and fenugreek leaves powder packed in different packaging materials namely glass jars, aluminium zip lock pouch + glass jar and plastic zip lock pouch + glass jar was studied and a reduction in the proximate and mineral content was observed for all three packaging materials. Significant reduction was observed for all the nutrient composition for products stored in plastic zip lock pouch + glass jar.

Effect of storage on the proximate composition of the value added products

The results of proximate composition of all the five products are presented from Table 2 and 3. As Table 2 depicts, the moisture content of matthi showed an increase after being stored in all the packaging materials.

Statistically significant increase was observed for matthi stored in plastic zip lock pouch + glass jar which was observed to be 3.44 per cent in fresh to 4.23 per cent in stored. Similar was the case in the crude protein and crude fiber of matthi when stored in plastic zip lock pouch + glass jar, a significant reduction was observed while for the matthi stored in glass jars and aluminium zip lock pouch + glass jar although a reduction was observed, it was not significant. Significant reduction in the crude fiber content was not observed while a significant reduction was observed in matthi stored in all three packages. Saha and Dunkwal (2009) also evaluation the shelf life quality with respect to nutritional composition of instant mixes used for the preparation of traditional Indian recipes like mathri and pakoda. They observed that the mixes stored in 200 gauge polythene for 3 months retained their nutritional composition but the fatty acid and free fatty acid content increased after 90 days of storage. Kalra et al., (1998) also observed an increase in the moisture content from 3.95 per cent to 57.48 per cent in matthi after 3 months of storage.

The effect of storage on the proximate composition of seviyan in different packaging materials has been depicted in Table 3 . Though an increase was observed in the moisture (2.53 to 3.10 per cent) and total ash content of seviyan stored in all packaging material, a significant increase was observed 
for those stored in plastic zip lock pouch + glass jar. Reduction in the crude protein and fat content was not statistically significant but better retention was observed for seviyan stored in glass jars and aluminium zip lock pouch + glass jar. Crude fiber showed no significant decrease in seviyan after storage.

Waghray and Gulla (2010) studied the shelf life of sev and boondi made incorporsating bengal gram flour and butylated hydroxyl anisole as an antioxidant packed in polypropylene cover for 4 months. They observed an increase in moisture content in Sev $(2.2 \%$ to $3.7 \%)$, and in boondi $(3.3 \%$ to $4.1 \%$ ). Peroxide value of $S e v$ (6.6 to $32.7 \mathrm{meq}$ ) and boondi ( 8.5 to $33.2 \mathrm{meq}$ ) also increased during storage.

Ambient storage behavior for sev packed in two different packaging materials viz. samples packed in high-density polyethylene (HDPE) and the samples stored in combination film (CF) the with atmospheric packaging (APS) was studied by Saurabh et al., (2013). They found that samples stored in combination film retained most nutrients during the storage when compared to those stored in HDPE. Kumari and Prakash (2009) observed that soy incorporated sorghum based seviyan stored in PET (polyethylene terephthalate) container was definitely better than steel, which was attributed to its low moisture and air ingress.

\section{Effect of storage on the mineral composition of the value added products}

The calcium and mineral content of the value added products stored in the different packaging materials were affected significantly after a period of 90 days storage as presented in Table 4. A significant reduction the mineral content in both the products was observed. The most reduction in calcium and iron was observed in matthi stored in Plastic zip pouch+glass jar. Whereas the reduction in iron content of matthi was retained better in both glass jar and $\mathrm{Al}$ zip pouch+glass jar. In the case of seviyan, calcium was retained mostly in both glass jar and Al zip pouch+glass jar and iron was mostly retained in $\mathrm{Al}$ zip pouch+glass jar followed by glass jar.

Effect of storage on the in-vitro protein digestibility of the value added products

The in -vitro protein digestibility decreased in both the developed products after storage period of three months as shown in Table 5.

The in- vitro protein digestibility of matthi showed significant decrease when stored in all three packaging materials after three months storage. A significant difference was found in case of in-vitro protein digestibility of seviyan stored in glass container + aluminium zip lock pouch as well as glass container + plastic zip lock pouch as compared to those stored in glass containers in which the decrease was not significant. Nicole and coworkers (2010) also reported a decrease in the in-vitro protein digestibility Ready-to-Eat composite porridge flours made by Soy-Maize-Sorghum-Wheat when stored in plastic pouches for 6 months. Preethi and Chimmad (2010) showed decrease in in-vitro protein digestibility of supplementary foods packed in ordinary zip lock packet after storage period of 45 days.

\section{Aflatoxin in the developed products}

Aflatoxins were not detected in any of the samples before and after the storage period. Aflatoxin B1 were not detected in the fresh samples of peanut flour based value added products like fryums, chutney powder, extruded snacks and noodles (Purohit and Rajyalakshmi 2011). Soher et al., (2013) studied the contamination of peanut samples by aflatoxins as well as in chicken burgers incorporated with deoiled peanut flour. 
Table.1 Microbial parameters analaysed and specific media used

\begin{tabular}{|l|}
\hline \multicolumn{1}{|c|}{ Test performed for } \\
\hline Aerobic Plate Count /Total Plate count (TPC) \\
\hline Yeast count \\
\hline Mold count \\
\hline Total coliforms \\
\hline Staphylococcus aureus \\
\hline Escherichia coli \\
\hline
\end{tabular}

\begin{tabular}{|c|}
\hline Media Used \\
\hline Nutrient Agar \\
\hline Glucose Yeast Extract Agar \\
\hline Potato Dextrose Agar \\
\hline Urinary Tract Infections Media \\
\hline Urinary Tract Infections Media \\
\hline Urinary Tract Infections Media \\
\hline
\end{tabular}

Table.2 Proximate composition of Matthi after storage in different packaging material

(Dry weight basis)

\begin{tabular}{|l|c|c|c|}
\hline \multicolumn{1}{|c|}{$\begin{array}{c}\text { Proximate composition } \\
\text { (g/ } / 100 \mathrm{~g})\end{array}$} & Glass jar & Aluminum zip lock pouch+ Glass jar & Plastic zip lock pouch + Glass jar \\
\hline Moisture (BS) & $3.44 \pm 0.014$ & $3.44 \pm 0.014$ & $3.44 \pm 0.014$ \\
\hline (AS) & $3.87^{\mathrm{b}} \pm 0.015$ & $3.92^{\mathrm{b}} \pm 0.030$ & $4.23^{\mathrm{a}} \pm 0.015$ \\
\hline Paired t-value & $6.82^{*}$ & $8.74^{*}$ & $10.94^{* *}$ \\
\hline Crude protein (BS) & $16.58 \pm 0.014$ & $16.58 \pm 0.014$ & $16.58 \pm 0.014$ \\
\hline (AS) & $16.35^{\mathrm{a}} \pm 0.020$ & $16.25^{\mathrm{b}} \pm 0.023$ & $15.99^{\mathrm{c}} \pm 0.017$ \\
\hline Paired t-value & $4.33^{\mathrm{NS}}$ & $2.65^{\mathrm{NS}}$ & $6.95^{*}$ \\
\hline Crude Fat (BS) & $20.92 \pm 0.040$ & $20.92 \pm 0.040$ & $20.92 \pm 0.040$ \\
\hline (AS) & $19.61^{\mathrm{a}} \pm 0.020$ & $19.66^{\mathrm{a}} \pm 0.016$ & $19.20^{\mathrm{b}} \pm 0.027$ \\
\hline Paired t-value & $4.15^{\mathrm{NS}}$ & $1.96^{\mathrm{NS}}$ & $7.49^{*}$ \\
\hline Crude Fiber(BS) & $1.43 \pm 0.161$ & $1.43 \pm 0.161$ & $1.43 \pm 0.161$ \\
\hline \hline (AS) & $1.39^{\mathrm{a}} \pm 0.178$ & $1.40^{\mathrm{a}} \pm 0.015$ & $1.36^{\mathrm{a}} \pm 0.040$ \\
\hline Paired t-value & $3.2^{\mathrm{NS}}$ & $4.28^{\mathrm{NS}}$ & $2.91^{\mathrm{NS}}$ \\
\hline Total ash (BS) & $0.88 \pm 0.017$ & $0.88 \pm 0.017$ & $0.88 \pm 0.017$ \\
\hline (AS) & $0.85^{\mathrm{a}} \pm 0.017$ & $0.83^{\mathrm{a}} \pm 0.008$ & $0.81^{\mathrm{a}} \pm 0.010$ \\
\hline Paired t-value & $10.00^{*}$ & $8.59^{*}$ & $10.00^{*}$ \\
\hline Carbohydrates (BS) & $60.47 \pm 0.056$ & $60.47 \pm 0.056$ & $60.47 \pm 0.056$ \\
\hline (by differences) (AS) & $59.86 \pm 0.021$ & $59.88 \pm 0.028$ & $58.98 \pm 0.034$ \\
\hline
\end{tabular}

Figures with different superscripts are significantly different $(p<0.05),{ }^{*}(p<0.05)$

BS- Before storage AS- After storage NS- Not significant

Table.3 Proximate composition of Seviyan after storage in different packaging material (Dry weight basis)

\begin{tabular}{|l|c|c|c|}
\hline \multicolumn{1}{|c|}{$\begin{array}{c}\text { Proximate composition } \\
\text { (g/ } / 100 \mathrm{~g})\end{array}$} & Glass jar & Pluminum zip lock pouch + Glass jar & Plastic zip lock pouch + Glass jar \\
\hline Moisture (BS) & $2.53 \pm 0.018$ & $2.53 \pm 0.018$ & $2.53 \pm 0.018$ \\
\hline (AS) & $2.72^{\mathrm{c}} \pm 0.012$ & $2.81^{\mathrm{b}} \pm 0.005$ & $3.10^{\mathrm{a}} \pm 0.017$ \\
\hline Paired t-value & $5.49^{*}$ & $9.50^{*}$ & $13.12^{* *}$ \\
\hline Crude protein (BS) & $23.49 \pm 0.280$ & $23.49 \pm 0.280$ & $23.49 \pm 0.280$ \\
\hline (AS) & $23.25^{\mathrm{a}} \pm 0.014$ & $23.35^{\mathrm{a}} \pm 0.049$ & $23.29^{\mathrm{b}} \pm 0.023$ \\
\hline Paired t-value & $4.60^{\mathrm{NS}}$ & $2.32^{\mathrm{NS}}$ & $10.94^{\mathrm{NS}}$ \\
\hline Crude Fat (BS) & $18.06 \pm 0.029$ & $18.06 \pm 0.029$ & $18.06 \pm 0.029$ \\
\hline (AS) & $17.93^{\mathrm{a}} \pm 0.008$ & $17.95^{\mathrm{a}} \pm 0.012$ & $17.88^{\mathrm{b}} \pm 0.020$ \\
\hline Paired t-value & $4.67^{\mathrm{NS}}$ & $3.07^{\mathrm{NS}}$ & $13.05^{\mathrm{NS}}$ \\
\hline Crude Fiber (BS) & $2.94 \pm 0.020$ & $2.94 \pm 0.020$ & $2.94 \pm 0.020$ \\
\hline (AS) & $2.85^{\mathrm{a}} \pm 0.020$ & $2.87^{\mathrm{b}} \pm 0.010$ & $2.88^{\mathrm{b}} \pm 0.008$ \\
\hline Paired t-value & $2.93^{\mathrm{NS}}$ & $0.18^{\mathrm{NS}}$ & $1.78^{\mathrm{NS}}$ \\
\hline Total ash (BS) & $1.79 \pm 0.012$ & $1.79 \pm 0.012$ & $1.79 \pm 0.012$ \\
\hline (AS) & $1.73^{\mathrm{a}} \pm 0.012$ & $1.75^{\mathrm{ab}} \pm 0.016$ & $1.71^{\mathrm{b}} \pm 0.025$ \\
\hline Paired t-value & $5.27^{*}$ & $10.06^{*}$ & $9.87^{*}$ \\
\hline Carbohydrates (BS) & $54.23 \pm 0.153$ & $54.23 \pm 0.153$ & $54.23 \pm 0.153$ \\
\hline (by differences) (AS) & $53.88 \pm 0.031$ & $53.72 \pm 0.089$ & $53.08 \pm 0.223$ \\
\hline
\end{tabular}

Figures with different superscripts are significantly different $(p<0.05),{ }^{*}(p<0.05)$

BS- Before storage AS- After storage NS- Not significant 
Table.4 Mineral composition of the value added products after storage in different packaging material (dry weight basis)

\begin{tabular}{|l|l|l|l|l|l|l|}
\hline \multicolumn{1}{|c|}{$\begin{array}{c}\text { Value added products in } \\
\text { different packaging } \\
\text { materials }\end{array}$} & \multicolumn{1}{|c|}{ BS } & \multicolumn{1}{|c|}{ AS } & t-value & \multicolumn{1}{c|}{ BS } & \multicolumn{1}{c|}{ AS } & \multicolumn{1}{c|}{ t-value } \\
\hline Matthi Glass Jar & $29.13 \pm 0.110$ & $25.23^{\mathrm{b}} \pm 0.026$ & $5.21^{*}$ & $4.18 \pm 0.008$ & $3.99^{\mathrm{a}} \pm 0.128$ & $8.51^{*}$ \\
\hline Al zip pouch+glass jar & $29.13 \pm 0.110$ & $25.59^{\mathrm{a}} \pm 0.336$ & $6.93^{*}$ & $4.18 \pm 0.008$ & $4.02^{\mathrm{a}} \pm 0.023$ & $5.56^{*}$ \\
\hline Plastic zip pouch+glass jar & $29.13 \pm 0.110$ & $20.45^{\mathrm{c}} \pm 0.017$ & $4.18^{* *}$ & $4.18 \pm 0.008$ & $3.52^{\mathrm{b}} \pm 0.066$ & $2.43^{*}$ \\
\hline Seviyan Glass Jar & $55.05 \pm 0.336$ & $53.17^{\mathrm{a}} \pm 0.026$ & $5.21^{*}$ & $4.98 \pm 0.032$ & $4.81^{\mathrm{b}} \pm 0.017$ & $5.21^{*}$ \\
\hline Al zip pouch+glass jar & $55.05 \pm 0.336$ & $53.25^{\mathrm{a}} \pm 0.210$ & $4.28^{*}$ & $4.98 \pm 0.032$ & $4.92^{\mathrm{a}} \pm 0.010$ & $4.28^{*}$ \\
\hline Plastic zip pouch+glass jar & $55.05 \pm 0.336$ & $52.18^{\mathrm{b}} \pm 0.082$ & $6.23^{*}$ & $4.98 \pm 0.032$ & $4.66^{\mathrm{c}} \pm 0.120$ & $6.23^{*}$ \\
\hline
\end{tabular}

Figures with different superscripts are significantly different $(p<0.05),{ }^{*}(p<0.05)$

BS- Before storage AS- After storage NS- Not significant

Table.5 In-vitro protein digestibility of the value added products after storage in different packaging material (dry weight basis)

\begin{tabular}{|l|c|c|c|}
\hline \multicolumn{1}{|c|}{$\begin{array}{c}\text { Value added products in } \\
\text { different packaging } \\
\text { materials }\end{array}$} & \multicolumn{1}{|c|}{ BS } & \multicolumn{1}{|c|}{ AS } & t-value \\
\hline Matthi Glass Jar & $60.22 \pm 0.28$ & $58.98^{\mathrm{a}} \pm 0.06$ & $4.55^{*}$ \\
\hline Al zip pouch+glass jar & $60.22 \pm 0.28$ & $59.09^{\mathrm{a}} \pm 0.11$ & $8.04^{*}$ \\
\hline Plastic zip pouch+glass jar & $60.22 \pm 0.28$ & $58.77^{\mathrm{b}} \pm 0.20$ & $8.50^{*}$ \\
\hline Seviyan Glass Jar & $68.68 \pm 0.05$ & $67.66^{\mathrm{b}} \pm 0.02$ & $2.12^{\mathrm{NS}}$ \\
\hline Al zip pouch+glass jar & $68.68 \pm 0.05$ & $66.98^{\mathrm{a}} \pm 0.03$ & $4.58^{*}$ \\
\hline Plastic zip pouch+glass jar & $68.68 \pm 0.05$ & $66.80^{\mathrm{c}} \pm 0.07$ & $7.23^{*}$ \\
\hline
\end{tabular}

Figures with different superscripts are significantly different $(p<0.05),{ }^{*}(p<0.05)$

BS- Before storage AS- After storage NS- Not significant

They noticed that aflatoxin G1 (AFG1) was absent in all peanut samples; whereas, trace amounts of aflatoxin G2 (AFG2) was detected and recorded $0.170,0.905$ and $0.760 \mu \mathrm{g} / \mathrm{kg}$, respectively for three samples out of five of the burger which was contributed by the growth in chicken meat.

Microbial quality of the value added products

Matthi and Seviyan developed and stored in three different packaging materials like glass jars, aluminium zip lock pouch + glass jar and plastic zip lock pouch + glass jar at $\left(30 \pm 2^{0} \mathrm{C}\right)$ for a periods of 90 days were of good microbial quality till 60 days of storage. An increase in the total plate count and fungal count was observed after 60 days of storage and it increased after 75 and 90 days of storage. The counts were lower in those products which were stored in glass jars and aluminium zip lock pouch + glass jar compared to those stored in plastic zip pouch + glass jar. The increase in the total plate count in matthi stored in different packaging materials after 75 days of storage was observed to be $1 \times 10^{4} \mathrm{cfu} / \mathrm{g}$ in glass jars as well as aluminium zip pouch + glass jar while it was $3 \times 10^{4} \mathrm{cfu} / \mathrm{g}$ for matthi stored in plastic zip lock pouch + glass jar.

The count increased to 2,2 and $3 \times 10^{4} \mathrm{cfu} / \mathrm{g}$ after 90 days of storage in for matthi stored in glass jar, aluminium zip pouch + glass jar and plastic zip lock pouch + glass jar respectively. The TPC counts ranged from $1-2 \times 10^{4} \mathrm{cfu} / \mathrm{g}$ and $2-3 \times 10^{4} \mathrm{cfu} / \mathrm{g}$ in seviyan stored in different packing materials after 75 and 90 days of storage respectively. 
The fungal count increased after 75 days of storage from $3-5 \times 10^{5} \mathrm{cfu} / \mathrm{g}$ and $2-5 \times 10^{5} \mathrm{cfu} / \mathrm{g}$ in matthi and seviyan respectively. The increase varied from $3-7 \times 10^{5} \mathrm{cfu} / \mathrm{g}$ in matthi and 3$5 \times 10^{5} \mathrm{cfu} / \mathrm{g}$ in seviyan, after 90 days of storage. The highest increase in the TPC as well as fungal counts was found for the products stored in plastic zip pouch + glass jar. However, E.coli and Staphylococcus spp. were not detected in any of the samples. Escherichia coli and Staphylococcus aureus counts were detected in chicken burger and chicken burger supplemented with $20 \%$ roasted defatted peanut flour (R-DPF) as 5.00 and $6.20 \log 10 \mathrm{CFU} / \mathrm{g}$ respectively) by Soher et al., (2013); however, only $E$ coli was decreased significantly in burger supplemented with $10 \%$ unroasted DPF and 20\% R-DPF. The authors also observed that the total fungal count decreased in burger supplemented with 10\% R-DPF. A decrease was observed in both total bacterial and fungal counts after storage at $-20^{\circ} \mathrm{C}$ for 60 days. Raja et al., (2014) observed a significantly ( $\mathrm{p}<0.05)$ increasing trend in the total plate count (log $\mathrm{cfu} / \mathrm{g}$ ) and yeast and mould count (log cfu/g) for the control as well as treatment samples of fish curls incorporated with corn flour, black gram flour and peanut flour on storage in LDPE pouches. Coliform counts (log $\mathrm{cfu} / \mathrm{g}$ ) were not detected until day 28 in all the products. The mean values for all the quality as well as the storage parameters were in the acceptable limits up to the day 21 of the storage.

The nutritional and microbial evaluation of the products namely Matthi and Seviyan developed and stored in three different packaging materials like glass jars, aluminium zip lock pouch + glass jar and plastic zip lock pouch + glass jar at $\left(30 \pm 2^{\circ} \mathrm{C}\right)$ for a periods of 90 days showed a reduction in all the proximate and mineral composition. An increase in the moisture content and growth of microorganism were observed after 90 days and 60 days of storage respectively. But the reduction in their nutritional profile and increase in the microbial load was significant in the products stored in plastic zip pouch + glass jar. Nutrients were better retained in glass jars and aluminium zip pouch + glass jar. Aflatoxin contamination was not detected in any of the samples. Hence, the present study reveals that glass jars and aluminium zip pouch + glass jar are the good packaging materials to store products prepared using partially defatted peanut cake flour and the products retained good microbial quality up to 60 days that is two months of storage.

\section{Acknowledgement}

I acknowledge Dr. Anita Kochhar for her immense support in designing the experiment as well as for providing all the necessary needed to conduct the experiment. I also acknowledge Dr. M. Javed for his guidance with the statistical analysis of the experimental data.

\section{References}

Akeson, W.R. and Stachmann, M.A. 1964. A pepsin pancreatin digest index of protein quality evaluation. J Nutr 83: 257-261.

Ali, N.1995. Post-harvest technologies for production of oilseed derivatives and value added products. Oilseed quality and value added products. Directorate of Oilseeds Research (ICAR), Progressive Press Pvt Ltd, New Delhi, pp 35-36

AOAC. 2000 Official Method of Analysis Association of Official Analytical Chemist, $17^{\text {th }}$ ed. Washington DC.

APC (American Plastics Council). 2004. Resin identification codes-plastic recycling codes. Arlington, Va.: American Plastics Council. Available from: http:// americanplasticscouncil.org/s apc/sec.asp.

Barabalok, R., Colbarn, C. R. and Smith, R. J. 1974 Rapid screening method for examining corn and corn derived products for possible aflatoxin contamination. J Assoc off Anal Chem 57:764-66

David, B. and Frankhausar. 2010. Pour plate technique for bacterial enumeration (Cited from http://biology.clc.uc.edu/frankhauser/Lab s/Microbiology/Meat_Milk/Pour_Plate.ht $\mathrm{ml}$ )

Desai, B.B., Kotecha, P.M., Salunkhe, D.K. 
1999b Groundnut protein product. In: Introduction science and technology of groundnut: biology, production, processing and utilization. Naya Prokash Publ, New Delhi, India, pp 546-582

Hotchkiss, J.J. 1997. Food-packaging interactions influencing quality and safety. Food Addit Contam 14(6-7):6017.

Kalra, C.L., Sehgal, R.C., Nagender, A., Mohan, L. and Berry, S.K. 1998. Preparation, quality standards and storage of matthi- a traditional savoury product. J Food Sci. Technol 35(1): 25-29

Kenneth, M. and Betty, B. 2007 Food Packaging-Roles, Materials, and Environmental Issues. Scientific status summary, Institute of Food technologists. The Society of Food Science and Technology. J Food Sci. 72 (3): 33-55

Kumari, R.K.R. and Prakash, J. 2009. Influence of soy protein incorporation on acceptability and shelf-stability of sorghum based 'seviya'. Indian J Sci Technol. 2(4): 53-59

Nicole M., Fei H.Y. and Claver I.P. 2010. Characterization of Ready-to-Eat Composite Porridge Flours Made by SoyMaize-Sorghum-Wheat Extrusion Cooking Process. Pakistan J. Nutr. 9 (2): 171-178

Piper, C.S. 1950 Soil and plant analysis. Interscience Publication, Inc. New York. Pp: 212

Preethi B. and Chimmad B. 2010. Utilization of linseed for value addition to supplementary food. Karnataka J Agric Sci 23(5):765-68.

Purohit, C. and Rajyalakshmi, P. 2011 Quality of products containing defatted groundnut cake flour. J Food Sci Technol 48:26-35

Raja, W.H., Kumar, S., Bhat, Z.F. and Kumar, P. 2014. Effect of ambient storage on the quality characteristics of aerobically packaged fish curls incorporated with different flours. Springer Plus. 3:106

Saha, R. and Dunkwal, V. 2009. Development and Nutritional Analysis of Value Added Spread Instant Mix. J Hum Ecol. 28(3): 187-190

Sashidhar, R.B., Bhat, R.V. and Vasanthi, S. 1989. Non-competitive Enzyme Linked Immuno-Sorbent Assay for detection of aflatoxin $\mathrm{B}_{1}$. Indian J Exp Biol 26:984-89.

Saurabh, S., Jyoti, J., Genitha, T.R. and Vikas, T.P.R. 2013. Studies on Development, Quality Evaluation and Packaging Materials on the Storage Stability of Snack Food (SEV). Intl J Agric Food Sci Technol 4(6): 515-522

Soher, E.A., Faham, S.E., Ibrahim, M.A., Hathout, A.S. and Sabry, B.A. 2013. Characterization and microbiological quality of low-fat chicken burger containing defatted peanut flour. J Applied Sci. Res. 9(11): 5599-5608

Waghray, K. and Gulla, S. 2010. Butylated Hydroxyanisole (BHA) to Maximize the Oxidative Stability of Snacks: A Case Study with Sev and Boondi. J Hum Ecol. 32(2): 97-99

\section{How to cite this article:}

Bindhya Dhanesh, T., Anita Kochhar and Javed, M. 2018. Effect of Storage on the Quality of Value Added Snacks Developed Using Partially Defatted Peanut Cake Flour and Fenugreek Leaves Powder. Int.J.Curr.Microbiol.App.Sci. 7(02): 1127-1135. doi: https://doi.org/10.20546/ijcmas.2018.702.140 